\title{
ASSEMBLY AND DISASSEMBLY OF MARINE PALEOCOMMUNITIES.
}

BUZAS, Martin A., Dept. Paleobiology, NMNH MRC-121, Smithsonian Institution, Washington, D.C.,20560, U.S.A.; CULVER, Stephen J., Dept. Palaeontology, The Natural History Museum, Cromwell Road, London SW7 5BD, U.K.

The Salisbury and Albemarle embayments of the North American Atlantic Coastal Plain have experienced numerous transgressions and regressions during the Cenozoic. Benthic foraminiferal communities of transgressive and high stand shelf deposits were enumerated from six formations ranging in age from Eocene to Pliocene. The species within each formation consist of immigrants and newly evolved species. Emigrants consist of surviving immigrants and surviving newly evolved species.

We documented the distribution of 311 immigrant and emigrant species in 137 well dated formations. Each species distribution is unique in space and time. The community does not behave as a unit.

The species of the Atlantic and Gulf Continental margins constitute a species pool. The composition of the pool is continually altered by origination and extinction of its members. During transgression immigrants are drawn from the pool with the environmental regime and chance acting as a filter. During regression emigrants disperse into various parts of the wide geographic area of the pool and become the potential immigrants for the next transgression.. 